\title{
Does financial depth impact economic growth in North Cyprus?
}

\author{
Turgut Türsoy $^{1 *}$ (D) and Faisal Faisal ${ }^{2}$
}

\author{
* Correspondence: \\ turgut.tursoy@neu.edu.tr \\ ${ }^{1}$ Near East University, Nicosia, North \\ Cyprus, Mersin 10, Turkey \\ Full list of author information is \\ available at the end of the article
}

\begin{abstract}
This study purpose is to connect the proxy of financial development which is total banking sector's deposits with the economic growth in North Cyprus. The reason for using the total deposit differently with the existing literature is because North Cyprus is bank-based financial system. Therefore, this study provides an analysis of the connection between finance-growth nexus in North Cyprus from 1978 through 2015, using the autoregressive distributed lag (ARDL) model and combined cointegration to evaluate and verify the relationship. In addition, this research added the inflation rate to the model specification to investigate the inflation-growth interaction. The results revealed that both methods of cointegration provided robust evidence for a long-run relationship between financial debt and growth. The ARDL long-run and short-run coefficients showed the positive impact of depth and the negative impact of inflation on economic growth, thereby confirming the strength of the financegrowth and inflation-growth connections. Moreover, financial depth had a larger coefficient than the inflation rate. Finally, the VECM Granger causality test provided evidence for unidirectional causality from the total deposits and inflation rate to economic growth in North Cyprus. These results are significant for the policymakers of North Cyprus because the findings show that economic growth can be improved by enhancing the deposit rates in the financial system.
\end{abstract}

Keywords: Financial depth, Inflation rate, Economic growth, ARDL, Granger causality JEL: G21, C22, E40

\section{Background}

North Cyprus ${ }^{1}$ is a small island economy. Over a period of 39 years, the banking sector in North Cyprus accumulated vast amount money in bank deposits. In the 1970's the total deposits in the banks of North Cyprus amounted to approximately USD 100 million. Because North Cyprus does not have any international economic and political relations with other countries except Turkey, the total deposits which is representing the total deposits amount into the banking sector (public and private banks) have increased 54-fold, reaching approximately USD 5 billion by the end of 2015. This amount is larger than the North Cyprus gross national product, which amounted to USD 3.7 billion in the same year. This deposits are belonging to it's of citizens and residence of the country.

The crucial question to be asked is whether these deposits, as an indicator of financial debt, had a substantial effect on economic performance. North Cyprus has a

(c) The Author(s). 2018 Open Access This article is distributed under the terms of the Creative Commons Attribution 4.0 International License (http://creativecommons.org/licenses/by/4.0/), which permits unrestricted use, distribution, and reproduction in any medium, provided you give appropriate credit to the original author(s) and the source, provide a link to the Creative Commons license, and indicate if changes were made. 
bank-based financial system, so banks are the primary institutions for funding individuals, investment projects, firms, and governmental agencies. Bank deposits, which constitute a significant share of the banks' liabilities, are the leading source of funds available for financing. Therefore, it is reasonable to expect that the amount of total deposits, as the main source of funds for economic activities, would have a substantial effect on economic growth.

Of course, the financial development in any country implies the improvement of financial services that should be supported by policies designed to increase their effectiveness and efficiency. Efficient financial intermediation allows capital to be allocated to the most profitable projects in the economy. Improved quality and depth in the financial sector leads to growth in the available funds, and channels the savings to the most highly productive opportunities. Therefore, demonstrating the relationship between depth and the economy can motivate the creation of policies that improve financial development and promote economic prospects.

Financial development is usually measured by many factors, including the depth and size of the financial system, among others. The World Bank classified the ratio of deposits to GDP as one indicator of financial depth. Beck et al. (2010) used the calculation of deposits as a share of GDP as an indicator of financial intermediary development. Arestis and Demetriades (1997) discussed evidence that the relationship between finance and growth utilises bank-based measures of financial development, such as the ratio of bank deposits to nominal GDP. However, the State Planning Organization, a governmental agency of North Cyprus, provides only the data for deposits, so the ability to measure financial depth is limited. Because the financial system of North Cyprus exhibits the characteristics of a bank-based financial structure, this study used the bank-based measurement of financial development, in the light of a substantial number of existing studies, to examine the relationship between finance and economic growth in North Cyprus.

In the existing literature as discussed above, various studies have explored the relationship between financial development and economic growth. This study also tries to investigate the financial-growth nexus and also using inflation rate as another regressor to contributes the existing literature in several ways. Firstly, in a manner that differs from the existing studies of North Cyprus, we used the banks' total deposits as the financial depth indicator to establish the relationship between finance and economic growth. Since the financial system of North Cyprus can be classified as bank-based, the accumulation of savings is an important indicator of the condition of the financial system. Secondly, we included the inflation rate in our empirical investigation, which is a new approach to assessing the relationship between finance and economic growth in North Cyprus. At the same time, this study examined the inflation-growth nexus. None of the previous studies of North Cyprus have included the inflation rate in their modelling and analysis of the finance-growth nexus. Lastly, another significant contribution of this work is that we used the quadratic match-sum method to convert the annual data to quarterly data to investigate the long-run and short-run relationships between depth, inflation, and growth. Prior studies used yearly data to investigate the long-run and short-run interactions, and used Granger causality to expound the finance and growth interaction. For this study, we used quarterly data ${ }^{2}$ from Q1 1978 to Q4 2015 to investigate the relationship under the autoregressive distributed lag (ARDL) bounds 
test combined with cointegration. However, the ARDL model suffers from problems identifying the cointegration order in a series because it is a single cointegration equation. Therefore, to improve the robustness of the results, our research also applied a combined cointegration test that produced more reliable results based on other conventional cointegration tests. After utilizing quadratic match sum method, the number of observations rose to 152. Additionally, this study applied Granger causality under VECM framework to investigate the direction of causation not only in the short and long-run but also joint causality. The limitation of this study was that there was no data available for other proxies of financial development. Hence, we used only total deposits as the financial depth indicator to establish a nexus between finance and growth.

The remainder of this paper is organised as follows. Section "Literature Review" presents the literature review. Sections "Model Specification and Data Collection4" explains the model specifications and data collection methods, while Section "Methodology" describes the empirical methodology. Section "Empirical Results" provides the empirical results and a discussion. Finally, Section "Conclusion and Policy Implications" concludes the study and offers an overview of policy implications.

\section{Literature review}

Without any doubt, the most watched indicator from the viewpoint of market participants and governmental institutions is economic growth. Economic growth is represented by significant indicators such as real GDP, as investigated and forecast by the work of Türsoy (2013) in North Cyprus.

Financial development is defined as the growth of the range and the size of financial activities. Theoretical studies have accepted the idea that the finance-growth nexus exists, and researchers have provided empirical evidence for the relationship between economic growth and financial development. For example, Schumpeter (1912) argued that a well-developed financial market provides higher profits for investors and entrepreneurs, which in turn promotes economic development. Accepting the finance-growth nexus and the role of the financial system in economic development provides the basis for evaluating future policy implications. An interruption in the financial system would impact the economy adversely. The financial crisis that began in 2008 showed the importance of a well-functioning financial system for the economy.

\section{Inflation-growth Nexus}

Fischer (1993) suggested that inflation reduces economic growth by causing a decrease in investment and growth of an economy. Empirical evidence for the relationship involved in the inflation-growth nexus showed that inflation has a negative effect on economic growth. Eggoh and Khan's (2014) empirical results validated the inflation-growth nexus. Rousseau and Wachtel (2002) investigated the relationship between the financial sector and economic growth in connection with the inflation rate. Their study found that periods of high inflation have adverse effects on economic growth, and also have implications for the finance-growth nexus. Haslag and Koo's (1999) investigation demonstrated the positive effects of depth and the adverse effects of inflation on economic growth. Hung (2003) developed a framework that allowed the inflation rate to play an important role in determining the finance-growth nexus. 


\section{Finance-growth Nexus}

The hypothesis that the financial system has a positive effect on growth was proposed and developed by Goldsmith (1969), McKinnon (1973), King and Levine (1993), and Rousseau and Wachtel (1998), and these studies showed that financial depth is related to economic growth.

Financial development plays a vital role for both developing countries and developed countries. In this connection, Faisal, Tursoy, and Berk (2018a) conducted a study to analyse the linear and non-linear relationship between financial development and Internet usage for Turkey. The study utilised the ARDL bounds testing approach to identify the evidence of cointegration. The authors reported strong evidence of a long-run relationship. Furthermore, asymmetric causality test was applied to investigate the asymmetric causal relationship between the estimated variables. The findings of their study highlighted the absence of any asymmetric causal relationship between financial development and economic growth.

In another study, Faisal et al. (2017a, b) analysed the relationship between economic growth, FDI, stock prices, and financial development. Their findings confirmed evidence of a long-run relationship between the estimated variables using the ARDL bounds testing approach. These results further highlighted the evidence of a causal relationship between financial development and economic growth in short-run, long-run, and joint causality testing. The results further implied the absence of both demand-following and supply-leading hypothesis in their studies. In another recent study, Faisal, Tursoy, and Resatoglu (2017b) investigated the nexus between economic growth and financial development for Pakistan. The findings of their study confirmed the evidence of both a demand-following and supply-leading hypothesis.

In addition, there has been some previous literature regarding financial development in the context of North Cyprus. For example, Güryay et al. (2007) investigated the finance-growth nexus by using the OLS method. The results showed that financial development did not cause economic growth between 1984 and 2003. This study used the depth variable to represent financial development; this variable was the ratio of government liabilities to GDP. Another study by Fethi et al. (2013) provided evidence for the financial sector's investment contributions to the output level of the North Cyprus economy in both the short-run and long-run. This study suggested a unidirectional causality from finance to growth.

Most of the studies in the literature ignored the role of structural breaks in the time series, but the data spans of most of the time series had series fluctuations that needed to be taken into account. In this paper, in addition to the conventional unit root test, we applied the structural break unit root test to identify the integration order of a series in the presence of structural breaks. Furthermore, we applied the work of Bayer-Hanck (2013) using combined cointegration, an approach that is more robust than the conventional Johansen cointegration test.

\section{Model specification and data Collection4}

Based on the above empirical study, in this section we provide the model specifications to obtain the impact of financial deepening and the inflation rate on economic growth. The nexus between financial development and inflation can be investigated using the following model: 


$$
L G N P p=(L D E P, I N F), L G N P p t=\propto i t+\beta 1 L D E P+\beta 2 I N F+\varepsilon t,
$$

where $\mathrm{L}$ represents the natural logarithm of the selected variables, and the beta coefficients show the long-run elasticities. $\varepsilon t$ is the white noise error term.

Our study covers the period from Q1 1978 to Q4 2015. To represent financial development, this study uses the total bank deposits (DEP) in North Cyprus as the indicator, following previous studies by Beck et al. (2010) and others. Economic growth is measured by the gross national product per capita (GNPp). Last, to capture the effects of the macroeconomic environment in North Cyprus, the inflation rate (INF) is used instead of the interest rate. For this period, the interest rate data is not available for North Cyprus.

In addition, this study uses the quadratic match-sum method to convert the annual data into quarterly data. Transforming the data from low frequency to high frequency adjusts and solves the problems related to seasonal variation. Therefore, as Cheng et al. (2012) and Faisal et al. (2018a, b) explained, the quadratic match-sum method decreases the variation in the data. Consequently, we use this approach because of its suitability for converting annual data into quarterly data.

\section{Methodology}

Before applying the ARDL bounds test for cointegration and Bayer-Hanck combined cointegration method to verify the long-run relationship between the variables, it is important to determine the order of integration by implementing the unit root test. Our study used the ADF (Dickey \& Fuller, 1979) and PP (Phillips \& Perron, 1988) unit root test methods to conduct the stationarity tests for the variables. The conventional unit root test cannot identify the evidence of the structural break unit root tests. Accordingly, this study also applied the Clemente-Montañés-Reyes test with one and two structural break unit root tests to identify the integration order in the presence of the structural break test.

To investigate the cointegration between the variables, such as LGNPp, LDEP, and LINF, this study used the ARDL bounds test method developed by Pesaran et al. (2001). The cointegration methods provided by Engle and Granger (1987), Johansen and Juselius (1990), and Phillips and Hansen (1990) were used to determine the long-run relationship between the variables. In addition, to verify the long-run relationship between the variables, we employed the combined cointegration approach originally proposed by Bayer and Hanck (2013) that combines four different methods together to estimate the joint cointegration between the variables.

The ARDL model for the standard functional specification between economic growth, deposits, and inflation rate is given as follows.

$$
\begin{aligned}
\Delta \ln G D P p=\beta_{0} & +\sum_{i=1}^{n 1} \beta_{1 i} \Delta \ln G D P p_{t-i}+\sum_{i=1}^{n 2} \beta_{2 i} \Delta \ln D E P_{t-i}+\sum_{i=1}^{n 3} \beta_{3 i} \Delta I N F_{t-i} \\
& +\lambda_{1} \ln G D P p_{t-1}++\lambda_{2} \ln D E P_{t-1}+\lambda_{3} I N F_{t-1}+v_{1} t
\end{aligned}
$$

Here, $v 1 t$ is the error term that is white noise, and $\Delta$ represents the first difference. To analyse cointegration among the selected variables, the bounds test is applied. The short run coefficients are tested jointly using the Wald test or a joint F-statistic. The 
value obtained from the F-statistic is then compared with the lower bounds and upper bounds critical values obtained as shown by Pesaran et al. (2001). If the value of the $F$-statistic lies above the upper bounds critical values, suggesting the evidence of a long-run relationship among the estimated variables. However, no conclusion can be drawn if the F-statistic's value lies between the UBCV's and LBCV's values. No evidence of cointegration exists if the F-statistic's value lies below the LBCV's value. The short-run equations under the ARDL framework can be written as shown:

$$
\begin{aligned}
\Delta \ln G D P p_{t}=\gamma_{0} & +\sum_{j=1}^{p 1} \gamma_{1 i} \Delta \ln G D P p_{t-i}+\sum_{j=1}^{p 2} \gamma_{2 i} \Delta \ln D E P_{t-i}+\sum_{j=1}^{p 3} \gamma_{3 i} \Delta I N F_{t-i} \\
& +\psi E C T_{t-1}+\vartheta t
\end{aligned}
$$

This study also checked the robustness of the estimation, which is provided by the ARDL approach with the combined cointegration methods. Bayer and Hanck (2013) confirmed the robustness using a single cointegration equation. Their combined cointegration test can be applied to those series that are integrated of the same order (Tursoy and Faisal, 2017, 2018). Furthermore, the results obtained in this test are based on the joint properties of the tests by Banerjee et al. (1998), Engle and Granger (1987), Boswijk (1994), and Johansen (1995) that provide more consistent and reliable results.

Bayer and Hanck's (2013) combined cointegration method is based on Fisher's formulas, and can be written with the cointegration test $P$-values as follows:

$$
\begin{aligned}
& \text { ENGGRA-JOHAN }=-2[\ln (\text { PENGGRA })+\ln (\text { PJOHAN })], \\
& \begin{aligned}
\text { ENGGRA }- \text { JOHAN }- \text { BOS }-\mathrm{BDM}=-2[\ln (\text { PENGGRA })+\ln (\text { PJOHAN }) \\
\quad+\ln (\text { PBOS })+\ln (\text { PBDM })],
\end{aligned}
\end{aligned}
$$

where PENGEGRA, PJOHAN, PBOS, and PBDM are the $p$ values for the different cointegration tests. The critical values have been obtained from Bayer and Hanck (2013).

After the cointegration methods have been applied to estimate the long-run relationship between the variables, the Granger causality test is applied to investigate the direction of the causality. When the long-run relationship is obtained from the cointegration test, then a Granger-type causality can be tested by augmenting the model with a single period lagged error correction term. Therefore, the vector error correction model (VECM) can be applied as follows:

$$
\begin{aligned}
\Delta \ln G D P p=\delta_{0} & +\sum_{i=1}^{p} \lambda_{1 i} \Delta \ln G D P p_{t-1}+\sum_{i=1}^{q} \lambda_{1 i} \Delta \ln D E P_{t-1}+\sum_{i=1}^{r} \lambda_{1 i} \Delta I N F_{t-1} \\
& +\phi_{1} E C T_{t-1}+e_{1 t}
\end{aligned}
$$

In the above equation, ECT represents the error correction term that is added to the model. With this equation, the Granger causality can be investigated in three forms: 
Table 1 Unit root estimation

\begin{tabular}{|c|c|c|}
\hline Variables & ADF & PP \\
\hline In $D E P_{t}$ & $-1.8441(9)$ & -0.0610 \\
\hline$\Delta \mathrm{ln} D E P_{t}$ & $-3.8655^{c}(8)$ & $-4.8303^{c}(9)$ \\
\hline In GNPp & $-0.7834(5)$ & $-0.5785(6)$ \\
\hline$\Delta \ln G N P p_{t}$ & $-3.9116^{c}(4)$ & $-5.4984^{\complement}(11)$ \\
\hline $\mathrm{INF}_{\mathrm{t}}$ & $-1.0721(6)$ & $-1.9830^{c}(1)$ \\
\hline$\Delta I N F_{t}$ & $-6.7518^{c}(5)$ & $-7.7174^{\complement}(5)$ \\
\hline
\end{tabular}

short-run, long-run, and joint. Based on the studies by Asafu-Adjaye (2000) and Masih and Masih (1996), short-run causality is determined by the Wald test to specify the significant coefficient using the first difference variables. The second form of causality can be identified with the error correction term in the system of the equation, as proposed by Masih and Masih (1996). Long-run causality is determined using the $t$-test or Wald test for the lagged error correction term. The last source of the causality, which was mentioned by Lee and Chang (2008), is tested using the relevant coefficient of the first difference series and the relevant coefficient of the lagged error correction term.

\section{Empirical results}

As explained previously, in this study the ARDL bounds test for cointegration was applied to investigate the impact of the banks' deposits and the inflation rate on economic growth in North Cyprus. Before reviewing the empirical results from the cointegration and Granger causality tests, first the ADF and PP unit root tests were used to examine the order of integration of the variables. Theoretically, the ARDL approach can be applied to the regressors, which are independent variables I (0), I (1), or a mixed order of integration. Based on Pesaran et al. (2001), the regressand and should be I (1). Therefore, to apply the bounds test for cointegration, we used unit root tests to examine the order of integration of the variables and to ensure that none of them was I (2) (Faisal et al., 2017a, b and Tursoy and Faisal, 2017, 2018; Faisal et al., 2018a, b).

Based on the findings in Tables 1, 2 and 3, it can be observed that all the variables had the same order of integration, which was I (1). In addition, the structural break

Table 2 Perron-Vogelsang test with one Endogenous Structural Break

\begin{tabular}{|c|c|c|c|c|c|}
\hline \multirow[t]{2}{*}{ Variables } & \multicolumn{5}{|c|}{ Perron-Vogelsang test with one Endogenous Structural Break } \\
\hline & AO -model & TB1 & IO-model & TB1 & Result \\
\hline & \multicolumn{2}{|l|}{ t-Statistics } & \multicolumn{3}{|l|}{ t-Statistics } \\
\hline In DEP $t_{t}$ & -2.667 & Jan 2008 & -1.522 & Jan 2001 & I (0) \\
\hline In GNPpt & -2.757 & Jan 2009 & -2.627 & Oct 2001 & I (0) \\
\hline $\mathrm{INF}_{\mathrm{t}}$ & -1.131 & July 1993 & -2.924 & Oct 1993 & I (0) \\
\hline \multicolumn{6}{|c|}{ First Difference } \\
\hline DIn DEP ${ }_{t}$ & $-5.996^{\mathrm{a}}$ & April 1981 & $-5.398^{\mathrm{a}}$ & Oct 2007 & I (1) \\
\hline DIn GNPp & $-5.172^{\mathrm{a}}$ & July 1989 & $-6.315^{\mathrm{a}}$ & Oct 1993 & I (1) \\
\hline $\mathrm{D} I N F_{\mathrm{t}}$ & $-4.664^{\mathrm{a}}$ & Oct 1993 & $-7.855^{\mathrm{a}}$ & Oct 1993 & I (1) \\
\hline
\end{tabular}

Note: ${ }^{\text {arepresents the significance at } 1 \% \text { level }}$ 
Table 3 Unit root test with two endogenous structural breaks: Clemente-Montañés-Reyes test

\begin{tabular}{|c|c|c|c|c|c|c|c|}
\hline \multirow[t]{2}{*}{ Variables } & \multicolumn{7}{|c|}{ Unit Root Test with Two Endogenous Structural Breaks: Clemente-Montañés-Reyes test } \\
\hline & AO -model & TB1 & TB2 & IO-model & TB1 & TB2 & Result \\
\hline & t-Statistics & & & t-Statistics & & & \\
\hline In $D E P_{\mathrm{t}}$ & -3.681 & Jan 1998 & Apr 2004 & -5.417 & Oct 1983 & Oct 2000 & I (0) \\
\hline $\ln G N P p_{\mathrm{t}}$ & -5.21 & Jan 1991 & Jan 2006 & -5419 & Oct 1987 & Oct 2001 & I (0) \\
\hline$I N F_{\mathrm{t}}$ & -3.052 & July 1993 & July 2002 & -4.033 & July 1993 & July 1994 & I (0) \\
\hline \multicolumn{8}{|c|}{ First Difference } \\
\hline DIn $D E P_{\mathrm{t}}$ & $-2.644^{a}$ & July 2000 & Oct 2007 & $-4.732^{\mathrm{a}}$ & Oct 2000 & Oct 2007 & I (1) \\
\hline Dln GNPp & $-5.870^{\mathrm{a}}$ & July 1989 & July 1994 & $-7.252^{\mathrm{a}}$ & Oct 1989 & Oct 1994 & I (1) \\
\hline $\mathrm{D} / N F_{\mathrm{t}}$ & $-12.017^{a}$ & July 1993 & July 1994 & $-14.671^{a}$ & Oct 1993 & Oct 1994 & I (1) \\
\hline
\end{tabular}

Note: ${ }^{a}$ represents the significance at $1 \%$ level

unit root tests, along with the break dates 1 and 2, identified the existence of a unique order of integration. Hence, we can conclude that all the series were non-stationary at this level; when taking the first difference, they became stationary. These results provided a suitable case for applying the ARDL bounds test for cointegration to investigate the impact of the regressors on economic growth.

As shown in Table 4, the results of the ARDL bounds test provided strong evidence for cointegration among the variables. The F-statistic value of the bounds test was 8.69, which was greater than the upper critical bounds value at $1 \%$. This finding suggested a strong long-run relationship between the concerned variables in this study.

After the long-run cointegration was observed by the bounds test, we developed the following tables to represent the short-run and long-run relationships between the variables. The results from the short-run estimation under the ARDL framework are shown in Table 5. It can be stated that deposits had a significant and positive impact on the economic growth in North Cyprus. However, the inflation rate affected the economic growth negatively and significantly. Moreover, the coefficient of the error correction term was negative and statistically significant at $1 \%$. This result confirmed the long-run relationship between the variables. The negative sign and significant coefficient of the lag of the error correction term suggested a

Table 4 Results of the Bounds test of Cointegration

\begin{tabular}{|c|c|c|c|c|}
\hline Estimated Model & $F_{\text {LnGNPp }}(\operatorname{LnC}$ & LnINF) & & \\
\hline Optimal Lag Length (AIC) & $(2,2,1)$ & & & \\
\hline F-Statistics (Bound Test) & $8.6992^{\mathrm{a}}$ & & & \\
\hline Critical Values & 1 Percent & 2.5 Percent & & $10 \%$ \\
\hline Lower Bounds I (0) & 4.99 & 4.37 & 3.88 & 3.38 \\
\hline Upper Bounds I (1) & 5.85 & 5.16 & 4.61 & 4.02 \\
\hline$R^{2}$ & 0.50 & & & \\
\hline Adj. $R^{2}$ & 0.49 & & & \\
\hline DW & 2.02 & & & \\
\hline F-Statistics & $75.40^{\mathrm{a}}$ & & & \\
\hline
\end{tabular}

Note: ${ }^{a}$ represents significance level at $1 \%$. The optimal lag length for ARDL model was chosen by AIC. The critical values mentioned in the above Table were obtained from Pesaran et al. (2001)

${ }^{\mathrm{b}}$ The ARDL model in this study was performed with unrestricted constant and restricted linear Trend (Case IV) 
Table 5 ARDL Short-run Results

\begin{tabular}{llll}
\hline Dependent Variable: $\Delta \operatorname{LnGNPp}(2,0,0)$ & & \\
\hline Cointegrating Form & Coefficient & Standard Error & t-statistics \\
Variable & 0.3308 & 0.0546 & 6.0490 \\
Constant & 0.4744 & 0.0636 & 7.4592 \\
$\Delta$ LnGNPp $_{\mathrm{t}-1}$ & -0.0875 & 0.0146 & -5.9600 \\
$\mathrm{ECT}_{\mathrm{t}-1}$ & 0.998 & Adjusted R-Squared & 0.998 \\
$\mathrm{R}-$ Squared & 0.0306 & D.W & 2.02 \\
S.E of regression & $23,784.31^{\text {a }}$ & \\
F-Statistics & &
\end{tabular}

Note: ${ }^{a}$, represents significance level at $1 \%$ and $5 \%$ levels, respectively

convergence from short-run disequilibrium to the long-run equilibrium. The speed of adjustment was approximately $8 \%$ in one quarter.

Parallel to the results in the short-run, the long-run estimation under the ARDL framework also confirmed the positive impact of deposits and the negative impact of inflation on the GNP per capita, as shown in Table 6 . The coefficient of the deposits was 0.8 , which suggested the greatest impact was on economic growth. The coefficient of inflation was -0.005 , which highlighted the adverse impact of inflation on the economy. The gain in the banks' deposits improved the economy positively by increasing the available funds for local profitable projects and investment, adding a positive contribution to economic development. Based on the findings by Tursoy and Faisal (2017, 2018), investment in North Cyprus was highly correlated with savings under the Feldstein and Horioka (FH) hypothesis. When the banking system experiences an increase in deposits, the rise in available funds augments the possibility of growth in the economy.

In contrast, high inflation affects the economy negatively, because inflation decreases purchasing power and makes the available funds costly for companies using the financial system. Therefore, high inflation causes a substantial rise in the interest rate either directly or indirectly, and thus increases the cost of funding. When funding costs are high, businesses are more willing to engage in highly risky activities to cover financing costs, which in turn increases the likelihood of bankruptcy. As expected based on this theoretical work, a negative relationship was found between inflation and economic growth.

The results of the diagnostic test for the ARDL model are reported in Table 7. These findings suggested the absence of any serial correlation between residuals and heteroscedasticity. We evaluated the stability of the results with the Ramsey RESET test. The test indicated that the estimated model was stable. All diagnostic tests confirmed the reliability and validity of the ARDL estimates.

Table 6 ARDL Long-run Results

\begin{tabular}{llll}
\hline Dependent Variable: LnGNPp & & & \\
\hline Variable & Coefficient & Standard Error & t-statistics \\
LnDEP & 0.8593 & 0.1364 & $6.2966^{\mathrm{a}}$ \\
LnINF & -0.0059 & 0.0034 & $-1.7203^{\mathrm{b}}$ \\
@TREND & -0.0126 & 0.0050 & $-2.5038^{\mathrm{a}}$ \\
\hline
\end{tabular}

Note: ${ }^{a}$ and ${ }^{b}$ represents significance at $1 \%$ and $10 \%$ respectively 
Table 7 Diagnostic Tests for long-run

\begin{tabular}{lllll}
\hline Diagnostic Test & $X^{2} \mathrm{SC}$ & $x^{2} \mathrm{BPG}$ & $X^{2} \mathrm{ARCH}$ & $\begin{array}{l}\text { Ramsey Reset Test } \\
\text { (F-Statistics) }\end{array}$ \\
\hline 2.8030 (0.3089) & $29.3910(0.803)$ & $\begin{array}{l}0.6941 \\
(0.4047)\end{array}$ & $\begin{array}{l}2.1090 \\
(0.0828)\end{array}$ \\
\hline
\end{tabular}

NOTE: $X^{2} \mathrm{SC}, X^{2} \mathrm{BPG}$ and, $X^{2} \mathrm{ARCH}$ are the Lagrange multiplier for serial correlation, Breusch-Pagan-Godfrey and ARCH test for heteroscedasticity, respectively. The numbers in the brackets are the $P$-Values. The F-Statistics was taken into the account when Ramsey RESET test was performed

To confirm the robustness of the ARDL bounds test for cointegration, the Bayer-Hanck combined cointegration test was conducted. The results are given in Table 8. These findings showed that the F-statistic values for ENG \& GRA and ENG \& GRA-JOHAN-BOS-BDM were greater than the critical values at $1 \%$, which rejects the null hypothesis that there is no cointegration. Therefore, this outcome provided evidence that the estimated variables were cointegrated.

In this study, the VECM Granger causality was also applied to investigate the direction of the causal relationship between the variables. Granger (1969) stated that VECM Granger causality provides evidence indicating whether the variables are cointegrated in a long-run relationship. Table 9 represents the causal relation between the GNP per capita, deposits, and inflation rate, and summarises the short-run, long-run and joint causality results. According to the coefficient of the lagged error correction term, there is evidence for a long-run relationship between the variables. Specifically, for the GNP per capita, a significant lagged error correction term was found. Unfortunately, significant coefficients were not found for the dependent variables for deposits and inflation. Furthermore, deposits and inflation were causing the GNP per capita in the short-run, which is represented by the lagged error term. Granger causality results implied that both financial development and inflation are causing the economic growth in North Cyprus. The disequilibrium in the short-run relationship is adjusting with approximately $4 \%$ with finance and inflation rate to the long-run equilibrium.

\section{Conclusion and policy implications}

In this study, we analysed the long-run and short-run relationship between economic growth, bank deposits, and the inflation rate in North Cyprus from Q1 1978 through Q4 2015. The ARDL bounds test for cointegration and the Bayer-Hanck combined cointegration method were used to examine the cointegration. The test results for both cointegration methods suggested a strong long-run relationship. Additionally, short-run and long-run equations were estimated under the ARDL framework. The coefficients for the long-run and short-run estimations confirmed a negative relationship between

Table 8 Bayer-Hanck cointegration test results

\begin{tabular}{|c|c|c|c|c|}
\hline \multirow[t]{2}{*}{ Model specification } & \multicolumn{2}{|c|}{ Fisher statistics } & \multirow[t]{2}{*}{ Lags } & \multirow[t]{2}{*}{ Cointegration Decisior } \\
\hline & ENG \& GRA & ENG \& GRA - JOHAN - BOS - BDM & & \\
\hline$F_{L n G N P}=f(L n G N P p / L n D E P, L n I N F)$ & $15.1347^{\mathrm{a}}$ & $43.3411^{\mathrm{a}}$ & 06 & Cointegration Exists \\
\hline Significance level & \multicolumn{2}{|c|}{ Critical values } & & \\
\hline Significance level at $1 \%$ & 16.72 & 32.601 & & \\
\hline Significance level at 5\% & 10.858 & 21.342 & & \\
\hline Significance level at $10 \%$ & 8.451 & 16.507 & & \\
\hline
\end{tabular}

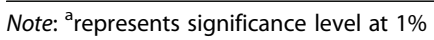


Table 9 Results of Granger Causality Tests

\begin{tabular}{|c|c|c|c|c|c|c|c|}
\hline \multirow[t]{2}{*}{ Dependent Variable } & \multicolumn{4}{|c|}{ F-Statistics (Probability) long-run } & \multicolumn{3}{|c|}{$\begin{array}{l}\text { Joint (Short-run and long-run) } \\
\text { F-Statistics (Probability) }\end{array}$} \\
\hline & $\Delta \mathrm{LGNPp}$ & $\Delta \mathrm{LDEP}$ & $\Delta \mathrm{INF}$ & $\begin{array}{l}E C T_{t-1} \\
{[t \text {-statistics }]}\end{array}$ & $\Delta \mathrm{LGNPp.ECT_{ \textrm {t } - 1 }}$ & $\Delta \mathrm{LDEP} . E C T_{\mathrm{t}-1}$ & $\Delta \mathrm{INF} . E C T_{\mathrm{t}-1}$ \\
\hline$\Delta \mathrm{LGNPp}$ & - & $\begin{array}{l}1.5909 \\
(0.1551)\end{array}$ & $\begin{array}{l}2.0758 \\
(0.0606)\end{array}$ & $\begin{array}{l}-0.0398 \\
{[-1.7680]^{c}}\end{array}$ & - & $\begin{array}{l}5.1313^{\mathrm{a}} \\
(0.0021)\end{array}$ & $\begin{array}{l}1.8377^{c} \\
(0.0857)\end{array}$ \\
\hline$\Delta \mathrm{LDEP}$ & $\begin{array}{l}0.9688 \\
(0.4492)\end{array}$ & - & $\begin{array}{l}0.1364 \\
(0.9913)\end{array}$ & $\begin{array}{l}0.0109 \\
{[0.9018]}\end{array}$ & $\begin{array}{l}1.1294 \\
(0.3489)\end{array}$ & - & $\begin{array}{l}0.2921 \\
(0.9559)\end{array}$ \\
\hline$\Delta \mathrm{INF}$ & $\begin{array}{l}0.0692 \\
(0.9987)\end{array}$ & $\begin{array}{l}0.3690 \\
(0.8974)\end{array}$ & - & $\begin{array}{l}-0.0347 \\
{[-1.2904]}\end{array}$ & $\begin{array}{l}0.2838 \\
(0.9592)\end{array}$ & $\begin{array}{l}0.6694 \\
(0.6975)\end{array}$ & - \\
\hline
\end{tabular}

Note: ${ }^{\mathrm{a}}{ }^{\mathrm{b}}$, crepresents significance at $10 \%, 5 \%$ and $1 \%$, respectively

the inflation rate and economic growth. These findings support the view that a high inflation rate can restrict economic activities in the economy of North Cyprus. Meanwhile, the coefficient of the proxy of financial development is positive and significant. This is supporting the view that investments which are supported by the available funds (deposits) are causing economic progress into the economy.

In addition, Granger causality confirmed a unidirectional causal relationship between economic growth and the inflation rate in North Cyprus. In addition, we demonstrated a positive relationship between deposits and economic growth. A high rate of deposits in the banking sector promotes economic growth within the economy by providing a substantial level of funds that can be allocated to investment activities. Based on the Granger causality test, none of the variables caused the country's deposits to increase. However, deposits did cause economic growth in North Cyprus, while the inflation rate had a unidirectional negative impact on economic growth.

These findings support the view that having a well-functioning financial system enhances economic activity in the North Cyprus economy. The results are significant for policy makers because the findings demonstrate that the economic growth of North Cyprus can be improved by enhancing the deposit rates in the financial system. Further development in the rate of savings entered into the banking sector would make more funds available for profitable projects. Possibly the best available option for the Central Bank of North Cyprus is to enhance the rate of deposits by adjusting the rediscount rate or bank rate i.e., the interest rate changed by the banking authority to affect the amount of reserve funds in the North Cyprus banks. This action would increase the amount of funds available to loan for economic activities.

\section{Endnotes}

${ }^{1}$ North Cyprus is used in this study to represents the Turkish Republic of Northern Cyprus which is established at 15 November 1983 and recognized by Turkey.

${ }^{2}$ The Quadratic match sum method has been utilized in this study to convert the annual data into quarterly data. Furthermore, this method is more useful in avoiding any seasonal variations that occurs in the data (Faisal, Tursoy and Berk (2018)).

Abbreviations

ARDL: Autoregressive Distributed Lag; FH: Feldstein \& Horioka; GDP: Gross Domestic Product; LBCV: Lower Bound Critical Value; UBCV: Upper Bound Critical Value; VECM: Vector Error Correction Model 
Availability of the data and materials

The data for the variables of this study were collected from the State Planning Organization of North Cyprus. The data is available with the website of devplan.org.

\section{Funding}

The Authors declare that no funding was received for this article.

\section{Authors' contributions}

$\pi$ proposed the subject of the article and determined the necessary strategies to investigate the direction of the manuscript. Mutually both authors performed together with the statistical analysis to prepare the results of the study. Both authors read and approved the final version of the document.

\section{Ethics approval and consent to participate}

Both authors are approving the article for ethical issues and consent to participate to the article.

\section{Consent for publication}

We would be willing to give the permission to the Journal of Financial Innovation to publish our article.

\section{Competing interests}

The authors declare that they have no competing interests.

\section{Author details}

${ }^{1}$ Near East University, Nicosia, North Cyprus, Mersin 10, Turkey. ${ }^{2}$ Institute of Business studies and leadership, Faculty of Business and Economics, Abdul Wali Khan University, Mardan, KP, Pakistan.

Received: 18 December 2017 Accepted: 4 June 2018

Published online: 21 June 2018

\section{References}

Arestis P, Demetriades P (1997) Financial development and economic growth: assessing the evidence. Econ J 107(442):783-799

Asafu-Adjaye J (2000) The relationship between energy consumption, energy prices and economic growth: time series evidence from Asian developing countries. Energy Econ 22:615-625

Banerjee A, Dolado J, Mestre R (1998) Error-correction mechanism tests for cointegration in a single-equation framework. J Time Ser Anal 19(3):267-283

Bayer C, Hanck C (2013) Combining non-cointegration tests. J Time Ser Anal 34:83-95

Beck T, Demirgüç-Kunt A, Levine R (2010) Financial institutions and markets across countries and over time: the updated financial development and structure database. World Bank Econ Rev 24(1):77-92

Boswijk HP (1994) Testing for an unstable root in conditional and structural error correction models. J Econ 63:37-60

Cheng, M, Chung, L, Tam, CS, Yuen, R, Chan, S, Yu, IW. Tracking the Hong Kong economy. Hong Kong monetary authority, occasional paper 03/2012. 2012

Dickey D, Fuller WA (1979) Distribution of the estimates for autoregressive time series with unit root. J Am Stat Assoc 74:427-431

Eggoh JC, Khan M (2014) On the nonlinear relationship between inflation and economic growth. Res Econ 68(2):133-143

Engle RF, Granger CW (1987) Co-integration and error correction: representation, estimation, and testing. Econometrica 55:251-276

Faisal F, Muhammad PM, Tursoy T (2017a) Impact of economic growth, foreign direct investment and financial development on stock prices in China: empirical evidence from time series analysis. Int J Econ and Financ Issues 6(4):1998-2006

Faisal F, Tursoy T, Resatoglu NG (2017b) Is there any causality between financial development, energy consumption and economic growth in Pakistan? Evidence from ARDL bounds testing approach and vector error correction model. Int J Ecol Econ and Stat ${ }^{\text {TM }}$ 38(2):33-48

Faisal F, Tursoy T, Berk N (2018a) Linear and non-linear impact of internet usage and financial deepening on electricity consumption for Turkey: empirical evidence from asymmetric causality. Environ Sci Pollut Res 25(12):11536-11555

Faisal F, Tursoy T, Gunsel Resatoglu N, Berk N (2018b) Electricity consumption, economic growth, urbanisation and trade nexus: empirical evidence from Iceland. Econ Res-Ekonomska Istraživanja 31(1):664-680

Fethi S, Katircioğlu S, Caglar D (2013) The role of the financial sector in the Turkish Cypriot economy: evidence from bounds and causality tests. Turk Stud 14(3):540-563

Fischer S (1993) The role of macroeconomic factors in growth. J Monet Econ 32(3):485-512

Goldsmith R (1969) Financial structure and development. Yale University Press, New Haven, CT

Granger CWJ (1969) Investigating causal relationships by econometric models and cross-spectral methods. Econometica 37:424-438

Güryay E, Şafakıı OV, Tüzel B (2007) Financial Development and Economic Growth: Evidence from Northern Cyprus. International research journal of finance and economics 8:57-62

Haslag J, Koo J (1999) Financial repression, financial development and economic growth. Federal Reserve Bank of Dallas Working Paper 99-02

Hung FS (2003) Inflation, financial development, and economic growth. Int Rev of Econ \& Finance 12(1):45-67

Johansen S (1995) A statistical analysis of cointegration for I (2) variables. Econ Theory 11(01):25-59

Johansen S, Juselius K (1990) Maximum likelihood estimation and inference on cointegration - with application to the demand for money. Oxf Bull Econ Stat 52:169-210

King RG, Levine R (1993) Finance and growth: Schumpeter might be right. Q J Econ 108:717-737 
Lee CC, Chang CP (2008) Energy consumption and economic growth in Asian economies: A more comprehensive analysis using panel data. Resour Energy Econ 30(1):50-65

Masih AMM, Masih R (1996) Energy consumption, real income and temporal causality: results from a multi-country study based on cointegration and error-correction modeling techniques. Energy Econ 18:165-183

McKinnon RI (1973) Money and Capital in Economic Development. The Brookings Institution, Washington, DC

Pesaran MH, Shin Y, Smith RJ (2001) Bound testing approaches to the analysis of level relationships. J Appl Econ 16:289-326

Phillips PC, Hansen BE (1990) Statistical inference in instrumental variables regression with I (1) processes. Rev Econ Stud 57(1):99-125

Phillips PCB, Perron P (1988) Testing for a unit root in time series regression. Biometrika 75:335-346

Rousseau PL, Wachtel P (1998) Financial intermediation and economic performance: historical evidence from five industrialized countries. J Money Credit Bank 30(4):657-678

Rousseau PL, Wachtel P (2002) Inflation thresholds and the finance-growth nexus. J Int Money Financ 21(6):777-793

Schumpeter, J., 1912, Theorie der Wirtschaftlichen Entwicklung [the theory of economic development]. Leipzig: Dunker \& Humblot [Cambridge, M.A.: Harvard University press, 1934. Translated by Redvers Opie]

Türsoy T (2013) "Forecasting Economic Growth Rate: the Case of North Cyprus". NEU J Soc Sci 6(1):193-207

Tursoy T, Faisal F (2017) Validity of FH hypothesis in small isolated island economy: an application of the combined cointegration approach. Asia-Pac J Account Econ 1-11

Tursoy T, Faisal F (2018) The impact of gold and crude oil prices on stock market in Turkey: empirical evidences from ardl bounds test and combined cointegration. Resources Policy 55:49-54

Submit your manuscript to a SpringerOpen ${ }^{\circ}$ journal and benefit from:

- Convenient online submission

- Rigorous peer review

- Open access: articles freely available online

- High visibility within the field

- Retaining the copyright to your article

Submit your next manuscript at $>$ springeropen.com 